\title{
PENINGKATAN PENALARAN MATEMATIS DAN MINAT BELAJAR PADA MATERI OPERASI HITUNG PENJUMLAHAN DAN PENGURANGAN DENGAN PENDEKATAN KONTEKSTUAL
}

\author{
Tomas Wahyu Aji P, Apri Damai Sagita Krissandi dan Marciana Sarwi
}

Universitas Sanata Dharma, Yogyakarta, Indonesia

Email: tompitaya@gmail.com, apridamai@gmail.com dan marcianasarwi@gmail.com

\section{INFO ARTIKEL \\ Diterima \\ 28 Mei 2021 \\ Diterima dalam bentuk revisi 08 Juni 2021 \\ Diterima dalam bentuk revisi 10 Juni 2021}

\section{Keywords:}

improved mathematical reasoning and interest in learning; $\quad$ contextual attachment; mathematics
Kata kunci:

peningkatan matematis dan minat belajar; penekatan kontekstual; matematika.

\section{ABSTRACT}

This study aims to improve students' mathematical reasoning and interest in learning with a contextual approach in mathematics. This study focuses on the addition and subtraction material learned by grade I students at SD Kanisius Kintelan in the even semester of the 2020/2021 school year. In this study, the method of classroom action research was carried out in two cycles. This study uses descriptive quantitative and qualitative descriptive analysis techniques. Qualitative data obtained from observations during the learning process. For quantitative data obtained from student test results. From the results of this study, it was found that there was an increase in mathematical reasoning and student interest in learning in grade I students of $S D$ Kanisius Kintelan on the addition and subtraction of Mathematics subjects. In this study, it was concluded that the contextual approach was able to improve mathematical reasoning and interest in learning in Mathematics with addition and subtraction material for the first grade of SD Kanisius Kintelan. Thus, this research is expected to be able to provide an overview for the school in order to create a learning process with a contextual approach so that students can easily understand and increase their interest in learning.

\section{ABSTRAK}

Penelitian ini bertujuan untuk meningkatkan penalaran matematis dan minat belajar peserta didik dengan pendekatan kontekstual dalam pelajaran Matematika. Penelitian ini fokus pada materi penjumlahan dan pengurangan yang dipelajari oleh peserta didik kelas I SD Kanisius Kintelan pada semester genap tahun pelajaran 2020/2021. Dalam penelitian ini menggunakan metode penelitian tindakan kelas yang dilakukan dalam dua siklus. Penelitian ini menggunakan teknik analisis deskriptif kuantitatif dan deskriptif kualitatif. Data kualitatif diperoleh dari observasi saat proses pembelajaran. Untuk data kuantitatif diperoleh dari hasil tes siswa. Dari hasil penelitian ini diperoleh bahwa ada peningkatan penalaran matematis dan minat belajar siswa pada siswa kelas I SD Kanisius Kintelan pada materi penjumlahan dan pengurangan mata pelajaran Matematika. 
Dalam penelitian ini disimpulkan bahwa pendekatan kontekstual mampu meningkatkan penalaran matematis dan minat belajar pada pelajaran Matematika dengan materi penjumlahan dan pengurangan kelas I SD Kanisius Kintelan. Dengan demikian, penelitian ini diharapkan mampu memberikan gambaran bagi pihak sekolah agar menciptakan proses pembelajaran dengan pendekatan kontekstual sehingga siswa mudah mengerti dann semakin menambah minat belajar siswa.

\section{Pendahuluan}

Menurut ( $\underline{\text { Fathani }}$, 2016) matematika adalah mata pelajaran yang melatih siswa untuk berpikir logis. Oleh sebab itu matematika harus dikuasai siswa sejak dini. Keterampilan penjumlahan dan pengurangan adalah salah satu tujuan dalam pembelajaran matematika. Untuk siswa kelas 1 SD operasi hitung penjumlahan dan pengurangan menjadi hal dasar untuk melangkah ke jenjang sekolah selanjutnya.

Menurut (Sabirin, 2014) matematika dijadikan sebagai patokan tingkat kecerdasan seseorang. Matematika mempunyai sifat khusus, yang tidak dimiliki oleh mata pelajaran lain. Karena hal tersebut belajar matematika juga harus dilakukan secara khusus, caranya dengan melatih kemampuan menalar, berpikir dan berimajinasi (Gazali, 2016). Matematika merupakan pelajaran yang memiliki keterkaitan antar materi (Rahayuningsih, 2017). Oleh sebab itu siswa kelas 1 harus mempunyai dasar operasi hitung penjumlahan dan pengurangan untuk melangkah ke materi selanjutnya.

Pembelajaran matematika perlu disampaikan dengan dengan metode-metode yang tepat supaya tujuan dalam pembelajaran yang diharapkan tercapai dan juga siswa dapat mencapai standar kompetensi dari pembelajaran itu sendiri. Salah satu langkah yang bisa dilakukan yaitu menggunakan pendekatan kontekstual.

Menurut (Suhana \& Hanafiah, 2014) pendekatan konstektual adalah cara belajar yang melibatkan antara materi yang diberikan kepada siswa dengan hal-hal yang nyata disekitar. Apabila semua siswa mampu menghubungkan dan menguraikan materi khususnya dalam operasi hitung penjumlahan dan pengurangan dengan konteks kehidupan yang dijalani siswa sehari-hari membuat siswa gampang dan terampil dalam memahami operasi hitung penjumlahan dan pengurangan (Kamalia et al., 2020).

Dari data yang peneliti peroleh mengenai kelas 1 SD Kanisius Kintelan 1, minat belajar siswa terhadap pelajaran matematika masih rendah dibuktikan dengan rata-rata minat siswa sebesar 59. Hal ini disebabkan karena guru belum tepat dalam menggunakan metode dan media, sehingga membuat kegiatan belar mengajar menjadi pasif, siswa tidak tertarik dengan apa yang disampaikan oleh guru. Menurut (Dewi, 2018) proses pembelajaran konvensional dengan cara ceramah, tanya jawab, dan pemberian tugah masih banyak dilakukan oleh guru. Dibutuhkan pendekatan yang tepat dalam menyampaikan materi supaya mudah dipahami oleh siswa. Untuk anak usia kelas 1 Sekolah Dasar tergolong dalam fase operasional konkrit, oleh sebab itu dalam menyampaikan materi pembelajaran supaya mudah dipahami adalah dengan pendekatan kontekstual. 
Dalam penelitian ini upaya yang dilakukan untuk meningkatkan penalaran matematis dan minat belajar siswa SD Kanisius Kintelan yaitu dengan menggunakan pendekatan kontekstual (Effendi, 2012). Pendekatan kontekstual adalah konsep belajar yang memadukan antara materi pelajaran yang disampaikan dengan hal-hal yang dilakukan dalam kehidupan sehari-hari siswa. Dengan konsep tersebut diharapkan siswa dapat memaknai setiap pembelajaran yang diterimanya dengan minat siswa dalam belajar dapat meningkat karena siswa akan diajak untuk terlibat aktif dalam kegiatan

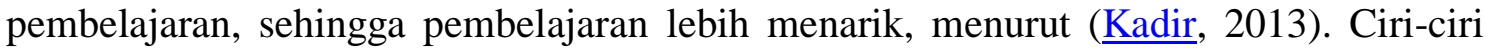

pembelajaran konstektual adalah, (a) kontribusi antara siswa dan guru, (b) saling membantu antara siswa dan guru, (c) belajar dengan penuh semangat, (d) bergelut dengan ide-ide, (e) menggunakan multimedia dan sumber belajar, (f) sharing bersama teman, (h) siswa aktif dan guru kreatif, (i) cara belajar siswa aktif, dan (j) melibatkan tujuh komponen utama pembelajaran efektif yakni : konstruktivisme, bertanya, menemukan, masyarakat belajar, pemodelan, dan penilaian sebenarnya. Dipilihnya pendekatan kontekstual ini diharapkan: (1) kegiatan belajar mengajar menjadi lebih menarik, karena siswa akan terlibat dalam kegiatan pembelajaran, (2) Guru tidak menggunakan metode konvensional, hal tersebut akan memicu minat siswa dalam pembelajaran (Sobron \& Bayu, 2019).

\section{Metode Penelitian}

Dalam penelitian ini menggunakan jenis Penelitian Tindakan Kelas. Penelitian Tindakan Kelas menurut ( $\underline{\text { Dis as }}, 2017$ ) PTK adalah penelitian yang dilaksanakan saat pembelajaran di kelas dengan maksud untuk meningkatkan kualitas pembelajaran. Menurut (Arikunto, 2010), Penelitian Tindakan Kelas terdiri dari tiga kata, yaitu penelitian, tindakan dan kelas: Penelitian, penelitian adalah aktivitas mengamati suatu objek dengan metode untuk mendapatkan data yang tepat, bertujuan untuk menaikan mutu objek yang diamati. Tindakan, tindakan adalah kegiata yang dilakukan dengan rencana dan maksud tertentu. Kelas, kelas adalah tempat berlangsungnya kegiatan belajar mengajar.

Penelitian Tindakan Kelas aktivitas berpikir yang sistematis dan empiris dalam upayanya menyelesaikan kendala yang ditemui oleh guru dalam pembelajaran (Sanjaya, 2016). Penelitian ini menggunakan model Kemmis dan Taggart. Penelitian ini terbagi menjadi II siklus, setiap siklusnya melalui tahap perencanaan tindakan, pelaksanaan tindakan, observasi dan refleksi. 


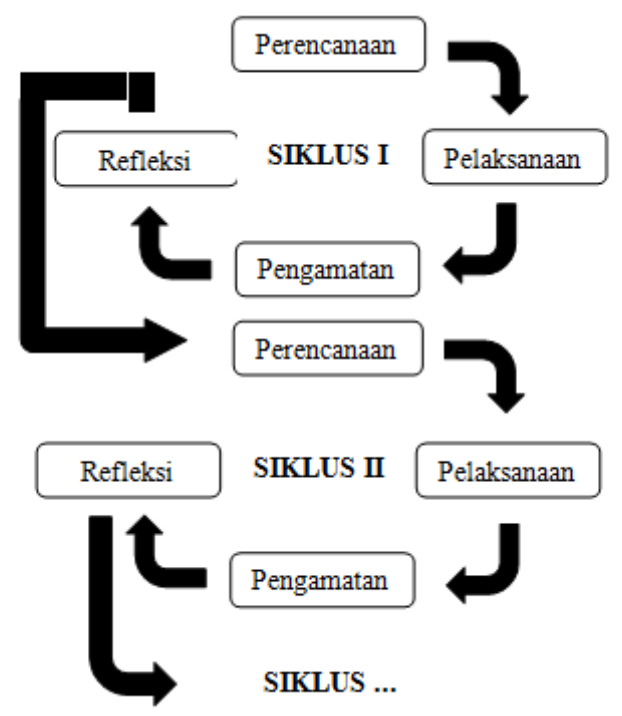

\section{Gambar 1 \\ Siklus Penelitian Tindakan Kelas}

Gambar di atas menunjukan langkah penelitian oleh Kemmis dan Mc.Taggart

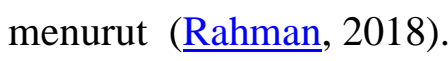

Subjek dalam penelitian ini adalah siswa-siswi kelas I SD Kanisius Kintelan tahun pelajaran 2020/2021 berjumlah 13 orang siswa. Siswa laki-laki berjumlah 10 siswa dan siswa perempuan berjumlah 3 siswa. Subjek penelitian ini didasarkan pada minat belajar terkhusus pada mata pelajaran matematika masih rendah. Rendahnya motivasi belajar siswa tersebut menyebabkan hasil belajar siswa juga belum maksimal sehingga perlu ditingkatkan. Objek dalam penelitian ini adalah peningkatan penalaran matematis dan hasil belajar siswa pada mata pelajaran matematika materi penjumlahan dan pengurangan dengan pendekatan kontekstual (Ruslan \& Santoso, 2013). Penelitian ini dilaksanakan selama 3 bulan, mulai Bulan Januari sampai dengan Bulan April 2021.

Pengumpulan data dilakukan dengan tes berupa soal pilihan ganda tentang materi penjumlahan dan pengurangan KD 3.4. Soal evaluasi diberikan kepada siswa melalui guru kelas dikirim melalui Whats App. Observasi dan pembagian angket untuk mengetahui motivasi mereka di dalam belajar. Adapun indikator minat pada seseorang antara lain: 1) berantusias mengikuti pelajaran karena didasari rasa suka, 2) mengikuti pelajaran dengan senang hati, 3) tertarik dengan materi pelajaran yang diberikan, dan 4) mampu memperhatikan pelajaran dengan sungguh-sungguh.

Gambaran tentang minat belajar didapat dari lembar kuesioner yang diberikan kepada siswa. Pada siklus I dan siklus II peneliti memberikan juga kuesioner untuk mengetahui minat belajar siswa. Pilihan jawaban yang disediakan diantaranya yaitu sangat setuju, setuju, tidak setuju, dan sangat tidak setuju.

Tabel 1

Ketentuan skor

\begin{tabular}{ll}
\hline Skor & Keterangan \\
\hline 1 & Sangat Tidak Setuju \\
\hline
\end{tabular}




\begin{tabular}{ll}
\hline Skor & Keterangan \\
\hline 2 & Tidak Setuju \\
\hline 3 & Setuju \\
\hline 4 & Sangat Setuju \\
\hline Sumber: Widojoko $(2014: 151)$
\end{tabular}

Sumber: Widoyoko (2014: 151)

Tabel 2

Kriteria Penskoran

\begin{tabular}{cl}
\hline Rentang Skor & Skor \\
\hline $81-100$ & Sangat Tinggi \\
\hline $66-80$ & Tinggi \\
\hline $56-65$ & Cukup \\
\hline $46-55$ & Rendah \\
\hline $0-45$ & Sangat Rendah \\
\hline
\end{tabular}

Pada akhir setiap siklus, siswa akan diberikan tes evaluasi. Setelah itu akan dihitung nilai rata-rata siswa untuk mengetahui peningkatan hasil belajar siswa.

Rata-rata kelas $=$ jumlah nilai siswa

Jumlah siswa

Sedangkan untuk menghitung persentase siswa yang tuntas adalah sebagai berikut:

Presentase $=\underline{\text { Jumlah nilai siswa yang tuntas }}$

Jumlah seluruh siswa

Indikator keberhasilan dalam penelitian ini yaitu nilai hasil tes siswa pada ranah kognitif sudah memenuhi Kriteria Ketuntasan Minimal (KKM) yang sudah ditentukan yaitu $\geq 70$.

\section{Hasil dan Pembahasan}

Penelitian dilaksanakan dalam dua siklus dalam dua kali pertemuan dengan waktu 2x35 menit. Pembelajaran yang dilaksanakan adalah pembelajaran tematik yang berfokus pada pelajaran Matematka materi pejumlahan dan pengurangan. Diakhir setiap siklus siswa diberikan soal tes evaluasi untuk mengukur penalaran matematis. Selain itu juga diberikan angket untuk mengetahui minat belajar siswa.

Hasil kuesioner yang dibagikan kepada siswa diperoleh hasil peningkatan minat belajar siswa. Kondisi awal rata-rata minat belajar siswa sebesar 65 dengan kategori cukup. Siklus I rata-rata minat belajar siswa sebesar 66 dengan kategori tinggi. Siklus II rata-rata minat belajar siswa sebesar 73 dengan kategori tinggi. Dari data tersebut menandakan adanya peningkatan minat belajar siswa. Berikut tabel peningkatan minat belajar siswa. 
Tabel 1

Minat Belajar

\begin{tabular}{ccc}
\hline Kondisi Awal & Siklus I & Siklus II \\
\hline 65 & 66 & 73 \\
\hline Cukup & Cukup & Tinggi \\
\hline
\end{tabular}

Penalaran matematis dalam penelitian ini juga menunjukan adanya peningkatan. Rata-rata hasil soal tes pada kondisi awal sebesar 67, dengan presentase siswa yang tuntas 30,7\%. Pada siklus I diperoleh hasil rata-rata sebesar 69, dengan presentase siswa yang tuntas 53,84\%. Siklus II diperoleh hasil rata-rata sebesar 76 dengan presentase siswa yang tuntas $76,92 \%$. Berikut adalah tabel hasil penalaran matematis:

Tabel 2

Hasil Penalaran Matematis

\begin{tabular}{lccc}
\hline \multicolumn{1}{c}{ Keterangan } & Kondisi Awal & Siklus I & Siklus II \\
\hline Skor Tertinggi & 80 & 87 & 100 \\
\hline Skor Terendah & 55 & 53 & 60 \\
\hline Rata-rata & 67 & 69 & 76 \\
\hline Ketuntasan & 4 siswa (30,7\%.) & 7 siswa $(53,84 \%)$ & 10 siswa \\
& & & $(76,92 \%)$. \\
\hline
\end{tabular}

Tabel di atas menunjukan pada kondisi awal terdapat 4 siswa yang sudah memenuhi kriteria ketuntasan minimal. Pada siklus I terdapat 7 siswa yang sudah memenuhi kriteria ketuntasan minimal. Kemudian meningkat pada siklus II menjadi 10 siswa yang sudah memenuhi KKM.

Dari data yang diperoleh, penalaran matematis siswa lebih maksimal ketika soal cerita yang diberikan dekat dengan kehidupan mereka sehari hari. Contohnya, "Anis mempunyai 5 apel, lalu apel Anis diberikan kepada adik sebanyak 2 apel. Berapa sisa apel Anis?" Selain itu siswa lebih mudah memahami soal ketika soal disajikan dengan gambar.

Dengan meningkatnya penalaran matematis siswa pada pelajaran Matematika berdampak pada minat belajar. Terbukti ketika siswa lebih berminat mengikuti pembelajaran yang disampaikan dengan menggunakan media pembelajaran berupa video. Pemanfaatan media pembelajaran berupa video tersebut sesuai dengan ciri khas pembelajaran kontekstual.

\section{Kesimpulan}

Dari hasil yang deperoleh dengan tes dan observasi terhadap pembelajaran Matematika dengan pendekatan kontekstual, ditarik kesimpulan bahwa pendekatan kontekstual mampu meningkatkan penalaran matematis dan minat belajar siswa untuk materi penjumlahan dan pengurangan pada mata pelajaran Matematika kelas I SD Kanisius Kintelan. 
Tomas Wahyu Aji P, Apri Damai Sagita Krissandi dan Marciana Sarwi

Penelitian ini diharapkan berguna untuk guru dan sekolah, supaya dapat menciptakan pembelajaran dengan pendekatan kontekstual sehingga siswa lebih mudah memahami materi yang diberikan dan lebih menarik minat belajar siswa. 
Peningkatan Penalaran Matematis dan Minat Belajar pada Materi Operasi Hitung

Penjumlahan dan Pengurangan dengan Pendekatan Kontekstual

\section{Bibliografi}

Arikunto, S. (2010). Penelitian Tindakan. In Yogyakarta: Aditya Media. Jakakar Aditya Media.

Dewi, E. R. (2018). Metode Pembelajaran Modern Dan Konvensional Pada Sekolah Menengah Atas. PEMBELAJAR: Jurnal Ilmu Pendidikan, Keguruan, Dan Pembelajaran, 2(1), 44-52. Https://Doi.Org/10.26858/Pembelajar.V2i1.5442

Disas, E. P. (2017). Analisis Kebijakan Pendidikan Mengenai Pengembangan Dan Peningkatan Profesi Guru. Jurnal Penelitian Pendidikan, 17(2). Https://Doi.Org/10.17509/Jpp.V17i2.8251

Effendi, L. A. (2012). Pembelajaran Matematika Dengan Metode Penemuan Terbimbing Untuk Meningkatkan Kemampuan Representasi Dan Pemecahan Masalah Matematis Siswa SMP. Jurnal Penelitian Pendidikan, 13(2), 1-10.

Fathani, A. H. (2016). Pengembangan Literasi Matematika Sekolah Dalam Perspektif Multiple Intelligences. Edu Sains: Jurnal Pendidikan Sains Dan Matematika, 4(2). Https://Doi.Org/10.23971/Eds.V4i2.524

Gazali, R. Y. (2016). Pembelajaran Matematika Yang Bermakna. Math Didactic: Jurnal Pendidikan Matematika, 2(3), 181-190.

Kadir, A. (2013). Konsep Pembelajaran Kontekstual Di Sekolah. Dinamika Ilmu: Jurnal Pendidikan, 13(1). Https://Doi.Org/10.21093/Di.V13i1.20

Kamalia, F. F., Basir, M. A., \& Ubaidah, N. (2020). Analisis Pemahaman Matematis Siswa Pada Materi Trigonometri. Indomath: Indonesia Mathematics Education, $3(1), 28-35$.

Rahayuningsih, S. (2017). Penerapan Model Pembelajaran Matematika Model Auditory Intellectually Repetition (AIR). Erudio Journal Of Educational Innovation, 3(2), 67-83.

Rahman, T. (2018). Aplikasi Model-Model Pembelajaran Dalam Penelitian Tindakan Kelas. CV. Pilar Nusantara.

Ruslan, A. S., \& Santoso, B. (2013). Pengaruh Pemberian Soal Open-Ended Terhadap Kemampuan Penalaran Matematis Siswa. Kreano, Jurnal Matematika KreatifInovatif, 4(2), 138-150.

Sabirin, M. (2014). Representasi Dalam Pembelajaran Matematika. Jurnal Pendidikan Matematika, 1(2), 33-44. http://dx.doi.org/10.18592/jpm.v1i2.49

Sanjaya, D. R. H. W. (2016). Penelitian Tindakan Kelas. Prenada Media.

Sobron, A. N., \& Bayu, R. (2019). Persepsi Siswa Dalam Studi Pengaruh Daring 
Tomas Wahyu Aji P, Apri Damai Sagita Krissandi dan Marciana Sarwi

Learning Terhadap Minat Belajar Ipa. SCAFFOLDING: Jurnal Pendidikan Islam Dan Multikulturalisme, 1(2), 30-38. https://doi.org/10.37680/scaffolding.v1i2.117

Suhana, C., \& Hanafiah, N. (2014). Konsep Strategi Pembelajaran. Bandung: PT Refika Aditama, 5(4), 3. 